\title{
A Review on Stabilization of Expansive Soil Using Industrial Solid Wastes
}

\author{
R. Thirumalai, S. Suresh Babu, V. Naveennayak, R. Nirmal, G. Lokesh \\ Department of Civil Engineering, Adhiyamaan College of Engineering, Hosur, India \\ Email: thirumalai063@gmail.com
}

How to cite this paper: Thirumalai, R., Suresh Babu, S., Naveennayak, V., Nirmal, R. and Lokesh, G. (2017) A Review on Stabilization of Expansive Soil Using Industrial Solid Wastes. Engineering, 9, 1008-1017. https://doi.org/10.4236/eng.2017.912060

Received: April 7, 2017

Accepted: December 24, 2017

Published: December 27, 2017

Copyright $\odot 2017$ by authors and Scientific Research Publishing Inc. This work is licensed under the Creative Commons Attribution International License (CC BY 4.0).

http://creativecommons.org/licenses/by/4.0/

(c) (i) Open Access

\begin{abstract}
In developing countries like India, Industrialization is rising rapidly, and also a great paucity of land is there, the demand for exploitation of industrial wastes which coming from industries is increasing. From geotechnical perspective, fly ash, granite and quarry waste, cement kiln dust, silica fume, rice husk etc. are the waste materials which have effectual features requisites by an excellent soil stabilization admixture. Stabilization using solid wastes is one of the different methods of treatment, to improve the engineering properties and make it suitable for construction. This paper briefs about the recent trends in stabilization of expansive soil using industrial waste (granite and quarry waste, cement kiln dust, silica fume, rice husk) as stabilizers for decreasing the environmental hazards.
\end{abstract}

\section{Keywords}

Expansive Soils, Soil Stabilization, Fly Ash, Granite and Quarry Waste, Cement Kiln Dust, Silica Fume, Rice Husk

\section{Introduction}

Stabilization is the process of mixing the material with soil to improve the soil strength and durability. In other words "Stabilization is a wide area to incorporate the various techniques to modify the properties of the soil". Widely, many types of stabilizer are available and used in the field of geotechnical engineering for stabilization of soil. But in recent time industrial solid waste is a big problem in developing countries like India, which causes hazards in nature like (Air, Land and Water Pollution) and needs large area of land to dump the solid waste. This is due to presence of high toxic substances. Some of the industrial solid wastes are fly ash, granite and quarry waste, cement kiln dust, silica fume, rice husk, etc. 


\section{Granite Wastes}

Granite wastes are the by-products that are obtained during the production of granites, when the raw stones were cut using gang saws to get the required shape of the granite stones. The granite powder or granite wastes are obtained. This powder flows along with the water forming marble slurry. Based on the lowest estimates of waste percentage, it can be estimated that industrial cluster produces around 8 lakh tonnes of waste per year. Granite slurry powders are of grain size less than 75 microns, with $90 \%$ of the samples are of grain size less than 25 $\mu \mathrm{m}$. In granite, $50 \%$ of the particle had a diameter lower than $5 \mu \mathrm{m}$. Chemical content of Granite waste has $\mathrm{SIO}_{2}$ as the major component $>60 \%$, with much lower level of $\mathrm{LOI}<2 \%$ with $\mathrm{AL}_{2} \mathrm{O}_{3}$ values between $6-14 \%$, $\mathrm{CaO}$ values of $0 \%$ $6 \%$ and traces of $\mathrm{Na}_{2} \mathrm{O}$ and $\mathrm{K}_{2} \mathrm{O}(0 \%-3.5 \%)$.

\section{Cement Kiln Dust}

Cement kiln dust is produced in the kiln during the production of cement clinker. Dust is in the form of minute separate particles mixture of partially calcined. And raw feed, clinker dust and ash is supplemented with alkali sulfates, halides. These particulates are captured by the exhaust gases and composed in particulate matter control devices such as cyclones, bag houses and electrostatic precipitators.

\section{Rice Husk}

Rice husk is produced from paddy cover. While milling paddy cover turns in to power. After milling of paddy, nearly $78 \%$ of weight converted as rice and left over $22 \%$ forms as husk. In past decade, husk is used as fuel for steam generation in parboiling of rice. Steam is generated by burning the husk. After burning, husk turns into ash which is known as rice husk ash (RHA). Its high amount of amorphous silica is $85 \%-90 \%$. For every $1000 \mathrm{kgs}$ of paddy milled, about 220 $\mathrm{kgs}(22 \%)$ of husk is produced, and it is burnt in the boilers, about $55 \mathrm{kgs}(25 \%)$ of RHA is generated.

\section{Review: Granite Waste and Quarry Dust}

Granite waste is a form of solid waste, generated from quarries and granite industries. By the addition of granite waste in black cotton soil it improves the unconfined compressive strength and CBR value $(1.81 \%-4.17 \%)$. In case of clay soil also it increases unconfined compressive strength by $15 \%$. This modification of soil properties is due to large amount of fine particles in the waste which fills the voids of soil. Quarry dust fills the voids of the soil as a result the OMC decreases and parallelly the MDD increases because the quarry dust improves the density of the soil and resist the entry of moisture. CBR value goes on increasing with increase in percentage of addition of quarry dust.

Dr. Akshaya Kumar Sabat (2012) [1] had worked in the lime stabilized expansive soil with quarry waste. The lime added were $2 \%$ to $7 \%$ at an increment of $1 \%$. The addition of quarry dust decreases the Liquid limit, Plastic limit, Plastic- 
ity index and increases the shrinkage limit of the expansive soil. Liquid limit, Plasticity index goes on decreasing. Shrinkage limit goes on increasing with increase in percentage of lime in expansive soil-quarry dust mixes.

The addition of quarry dust decreases the OMC and increases the MDD of the expansive soil. OMC goes on increasing and MDD goes on decreasing with increase in percentage of lime in expansive soil-quarry dust mixes and up to $5 \%$ of lime content the MDD of expansive soil-quarry dust mix is greater than that of virgin soil. The addition of quarry dust to expansive soil decreases the cohesion and increases the angle of internal friction. With the addition of lime to soilquarry dust mixes, the cohesion and angle of internal friction value increases up to $5 \%$ addition of lime and decreases with further increase in lime content. Addition of lime makes the soil-quarry dust mixes durable. The percentage reduction of UCS is lowest at $5 \%$ lime addition.

Akshaya Kumar Sabat \& Bidula Bose (2013) [2] conducted some laboratory test on black cotton soil by the way of mixing Fly ash and quarry dust in the proportion of 1:2 were added to an expansive soil up to $75 \%$ of its dry mass. Fly ash added were $0 \%$ to $25 \%$ at an increment of $5 \%$ and quarry dust $0 \%$ to $50 \%$ at an increment of $10 \%$ by dry mass of the soil. The mixes were prepared in such a manner that their percentages were $100 \%$, like soil: fly ash: quarry dust: 70:10:20 etc and get some result of The MDD goes on increasing and the OMC goes on decreasing with increase in percentage of addition of fly ash-quarry dust mixes. The maximum value of UCS is achieved, when the percentage of fly ash-quarry dust mix is $45 \%$, further addition of fly ash-quarry dust mixes decreased the UCS. The CBR goes on increasing with increase in percentage of addition of fly ash-quarry dust mixes. The cohesion goes on decreasing and the angle of internal friction goes on increasing with the increase in percentage of addition of fly ash-quarry dust mixes. The swelling pressure is found to be $12 \mathrm{kN} / \mathrm{m}^{2}$ when the percentage of fly ash-quarry dust mix is $45 \%$ which will not create any problem if a pavement is constructed over the expansive soil subgrade stabilized at this percentage of fly ash-quarry dust mix.

Parte Shyam Singh, Yadav R.K. (2014) [3] had added marble dust to black cotton soil at an increment of $10 \%$ and found that DFS (Differential Free Swell) value reduced from $66.6 \%$ to $20 \%$ and addition of marble dust increase "UCS" from $110.86 \mathrm{KN} / \mathrm{m}^{2}$ to $175.46 \mathrm{KN} / \mathrm{m}^{2}$. The soaked $\mathrm{CBR}$ values have also increased significantly with the addition of marble dust content. The addition of $40 \%$ marble dust into the black cotton soil, increase the CBR values from $1.81 \%$ to $4.17 \%$.

Arun Patidar \& Dr. H.K. Mahiya (2014) [4] had analyze the property of soil by mixing fibre in various percentage of $0.5,1.0,1.5$ with plain soil, stone dust is mixed in various percentage of $5,10,15$ with plain soil, and Lime is mixed in various percentage of 3,6,9 with plain soil. There tests on find out optimum value of all the materials and mixed with combination of fibre (1\%), stone dust (10\%) and Lime (6\%) with plain soil and they got a positive results as Liquid limit and plastic limit of Black Cotton soil decrease with increasing\% Lime. But Liquid limit and 
plastic limit of Black Cotton soil increase with increasing\% stone dust and\% fibre. CBR value of Black Cotton soil is maximum with combination of fibre (1\%), stone dust (10\%) and Lime (6\%). UCS value of Black Cotton soil increases with varying percent of fibre, stone dust and lime. Permeability of Black Cotton soil decreases with increasing\% of stone dust and lime.

By designing the two lane road treated with combination of fibre (1\%), stone dust (10\%) and lime (6\%) having $12 \% \mathrm{CBR}$, it is found that reduction in subbase layer thickness is of the order of $40 \%$ and the overall cost of 22 lacks pavement reduced.

Ankur Mudgal, et al. (2014) had studied the effect of stone dust on black cotton soil and concluded that MDD of lime stabilized (9\%) Black Cotton Soil increases up to the addition of $20 \%$ Stone Dust and further increase of the agent decreases the value. Similarly, for UCS and CBR, the strength increases up to $20 \%$ addition of Stone Dust in lime stabilized soil. The reason of this effect is the pozzolanic reactions of lime with the amorphous silica and alumina present in soil and Stone Dust. SEM (Scanning Electron Microscopy) Pictures of cured sample clearly shows coarser bonded particles of Black Cotton Soil, Lime and Stone Dust. X-Ray diffraction of samples shows the presence of montmorillonite, vermiculite (minerals of smectite group), in Black Cotton Soil, whewellite and Quartz in Stone Dust and dolomite calcite in lime.

Surabhi Chawda (2014) [5] has described the effect of crusher dust on the engineering characteristics of Black Cotton soil is presented in this paper. The oven dried black cotton soil with lime (5\%) and crusher dust in different proportion (10\%, $20 \%$ respectively) are mixed together in proportions by weight to form various mixes. The formed dry mixes are being blended together with water in order to get a homogenous blend. He got the modified values of engineering properties as the Liquid limit values of the samples are decreasing with increase in the amount of crusher dust.

Shrinkage limit is increasing from $14.4 \%$ to $15.4 \%$ with the increase in the percent of crusher dust, indicating that the degree of expansion changes from "critical" to "non critical" state. There is marked reduction in Plasticity Index values (31.85\% to $6.8 \%)$, if the BC soil is mixed lime and crusher dust. The lime stabilized $\mathrm{BC}$ soil mixed with crusher dust changed the proctor compaction parameters. There is a decrease in OMC and increase in MDD with the increase of crusher dust in lime stabilized BC soil. It is observed that when lime stabilized clay sample is mixed with $20 \%$ crusher dust the MDD increased from $1.58 \mathrm{~g} / \mathrm{cc}$ to 1.81 $\mathrm{g} / \mathrm{cc}$ with decrease in OMC from $22 \%$ to $14.3 \%$.

Akanbi, D.O., et al. (2014) had conducted laboratory test on stabilization of black cotton soil with Quarry dust and observed that Dadin-kowa black cotton soil is low plastic clay which is unsuitable as a base course material. It can be classified as an A-6 soil by AASHTO system and CL (clay with low plasticity) by the unified soil classification system (USCS). CBR value obtained from test of the untreated black cotton soil (preliminary test) shows that the soil requires modification and stabilization before usage as material in road construction. The UCS val- 
ues increases with increase in number of curing days due to the hydration properties of the cement thus giving a maximum value of $1880 \mathrm{kN} / \mathrm{m}^{2}$ for 28 days curing. The 7 days UCS value of $1616 \mathrm{kN} / \mathrm{m}^{2}$ does not meet the adopted criterion of $1730 \mathrm{kN} / \mathrm{m}^{2}$ recommended by the TRRL (1977) but the CBR value of $186 \%$ was satisfied as compared with the Nigerian General Specification (1997) of $180 \%$. The Dadin-kowa black cotton soil can be stabilized economically using a mixture of $6 \%$ cement $+20 \%$ Q.D. as this combination satisfied the condition for use of material as a base course with $20 \%$ cement saving, as compared with using only cement.

Muthu Kumar M., Tamilarasan V. S. (2015) [6] had added marble waste. They study the behaviour of the soil using marble powder by adding marble powder with clay $0 \%-25 \%$ at an interval of $5 \%$. As a result of that the maximum unconfined compressive strength of the clay is $215 \mathrm{kN} / \mathrm{m}^{2}$ at $15 \%$ of marble powder. The Marble Powder is added about 15\% to the soil as strength point of view. The expansive soil was modified in to low plasticity and silty behaviour.

H. Venkateswarlu et al. (2015) [7] had studied the effect of black cotton soil after treated with Quarry dust and observed that the liquid limit and plastic limit decreasing irrespective of the percentage of addition of Quarry Dust. It was found that the Maximum Dry Density attained at 10\% Quarry Dust and OMC goes on decreasing with increase in percentage of Quarry Dust and noticed that the Un-soaked CBR goes on increasing with increase in percentage of addition of Quarry Dust. It was found that cohesion goes on decreasing with increase in percentage of quarry dust. From the experimental analysis it is found that Quarry Dust up to $10 \%$ can be utilized for strengthening the expansive soil with a substantial save in cost of construction.

Brajesh Mishra, Ravi Shanker Mishra (2015) [8] had added some percentage of fly ash with Black Cotton Soil and find its behavior and also Mix some percentage of ferric chloride and some percentage of sand dust with Black Cotton Soil and it was observed that the liquid limit was decreased by $22.41 \%$ with addition of $2.5 \%, \mathrm{FeCl}_{3}, 15 \%$ fly ash and $25 \%$ stone dust. Plastic limit of black cotton soil was increased by $9.58 \%$ for $2.5 \%, \mathrm{FeCl}_{3}, 15 \%$ fly ash and $25 \%$ stone dust addition to black cotton soil and the results show that there was a increase in maximum dry density of black cotton soil from $1.624 \mathrm{~g} / \mathrm{cm}^{3}$ to $1.915 \mathrm{~g} / \mathrm{cm}^{3}$ for $2.5 \%$, $\mathrm{FeCl}_{3}, 15 \%$ fly ash and $25 \%$ stone dust addition to black cotton soil. It was observed that C.B.R. value was increase by $170.83 \%$ for $2.5 \%, \mathrm{FeCl}_{3}, 15 \%$ fly ash and $25 \%$ stone dust addition to black cotton soil. The increase in C.B.R. value is an indication of improvement of soil properties and its strength to counter the resistance to penetration resulting in a decrease in pavement thickness and reduction in cost of construction of pavement.

\section{Review: Cement Kiln Dust}

Cement kin dust is produced by cement industries in large amount. Many attempts have been made to use CKD for various purposes. One of this soil stabilization, by adding $\mathrm{CKD}$ the initial $\mathrm{pH}$ value, unconfined confined compression 
strength, stiffness of the clay increases due to free lime content in CKD. Similar to clay soil black cotton soil also has the improved properties. Gradual increase in permeability from $4.80 \times 10^{-4} \mathrm{~cm} / \mathrm{s}$ to $1.43 \times 10^{-3} \mathrm{~cm} / \mathrm{s}$ which leads to the pervious material property, as well as reduces the swelling nature significantly increasing UCS from $142 \mathrm{kN} / \mathrm{m}^{2}$ to $178 \mathrm{kN} / \mathrm{m}^{2}$.

Peethamparan and Olek (2008) had examined the stabilizing effect of four cement kiln dusts (having different physical and chemical characteristics) on Na-Montmorillonite clay. The cement kiln dusts decreased the plasticity index (Ip), increased the initial $\mathrm{pH}$ value, UCS and stiffness of the clay. The free lime content of the cement kiln dust was found to be the most significant parameter for the effectiveness of the stabilization along with the duration of curing period.

F.O.P. Oriola and G. Moses (2011) [9] conducted Laboratory tests on black cotton soil treated with up to $16 \%$ Cement Kiln Dust (CKD) by dry weight of soil to assess its suitability for use in waste containment application. Specimens were prepared at molding water contents $-2 \%, 0 \%,+2 \%$ and $+4 \%$ of the optimum moisture content at the compactive energy levels of British Standard Light (BSL) and West African Standard (WAS).As a result the UCS show a general improvement in strength for up to $16 \%$ CKD treatment this is largely as a result of the pozzolanic input of $\mathrm{CKD}$, which produced stronger bonds. Treated black cotton soil produced improved volumetric shrinkage strain values at both BSL and WAS compactive efforts. But regulatory minimum VSS values were achieved only at $12 \%$ CKD for BSL, while $12 \%$ and $16 \%$ CKD treatment produced successful results for WAS compactive effort.

G. K. Moses et al. (2012) had conducted Laboratory test on black cotton soil treated with up to $16 \%$ Cement Kiln Dust (CKD) by dry weight of soil to assess its suitability for use as road pavement material. Natural soil treated with CKD gave a peak 7 day UCS value of $381 \mathrm{kN} / \mathrm{m}^{2}$ and $410 \mathrm{kN} / \mathrm{m}^{2}$ at $12 \%$ and $8 \%$ CKD content at BSL and WAS energy level respectively. This values fall short of 1710 $\mathrm{kN} / \mathrm{m}^{2}$ specified by TRRL (Transport and Road Research Laboratory) (1977) for base materials stabilization using OPC. And this value also fails to meet the requirement of $687-1373 \mathrm{kN} / \mathrm{m}^{2}$.

J. Marku et al. (2012), had experienced cement kiln dust with black cotton soil and obtained that The Cement Kiln Dust have chemical, mineralogical and physical characteristics quite different from Portland cement. They vary depending on raw materials, type of kiln operation, dust collection systems, fuel type used in cement clinker production, etc. The CKD strength gain contribution in the CKDPC blends is low. It seems that the CKD used has not self cementitious value due to the absence of calcium silicates and its low fineness. It is possible to use of the CKD as partial replacement of PC, in combination with pozzolanic materials, like fly ash, blast furnace slag, etc., in certain mortar mixed designs without lowering the main characteristics of the product.

Y. Keerthi et al. (2013) had observed that, Kiln ash has characteristics that can improve the engineering characteristics of tropical lateritic soils; The recorded 
improvements in the compressibility decrease and permeability Ots and observed that the liquid limit, plastic limit, plasticity index are decreasing by the addition of $\mathrm{CKD}$ up to $10 \%$ and then further increases with the increase in CKD percentage. The optimistic mix proportion based on the LL, PL, PI is 81:15:4 (Clay:CKD:RBI Grade 81). The Maximum Dry Density is decreasing and Optimum Moisture Content is increases with increase in percentage of CKD at different proportions may be due to water adsorption reduction. The MDD is increasing and OMC is decreasing at the combination of $4 \%$ RBI Grade 81 and 15\% CKD content. It gives the optimum value at 81:15:04 (Soil:CKD:RBI) proportion. The unconfined compressive strength of stabilized samples increases with increase in percentage of CKD and RBI grade 81 . The unconfined compressive strength of stabilized samples increases with increase in 3, 7 and 28 days of curing. The shear strength cohesion values are increasing for combinations of CKD and RBI Grade 81. Unsoaked CBR value of soil increases with increasing the percentages of CKD and RBI Grade 81.

Vivek Singh et al. (2015) has studied that Addition of cement kiln dust into the black cotton soil has changed the proctor compaction parameters. The OMC of the BCS has decreased and Maximum dry density (MDD) increased with the addition of cement kiln dust. There is significant decrease in swelling characteristics of the soil. The DFS (Differential Free Swell) values are reduced from 31\% to $5 \%$, indicating that the degree of expansiveness has reduced from high to low. Soaked CBR values have also increased with the addition of cement kiln dust content. The addition of $25 \%$ cement kiln dust into the black cotton soil, increases the CBR value from $1.514 \%$ to $3.54 \%$. There is a gradual increase in permeability from $4.80 \times 10^{-4} \mathrm{~cm} / \mathrm{s}$ to $1.43 \times 10^{-3} \mathrm{~cm} / \mathrm{s}$ which leading to the pervious material property. Addition of cement kiln dust also increased the unconfined compressive strength (UCS). The UCS stabilized samples significantly increased from $142 \mathrm{KN} / \mathrm{m}^{2}$ to $178 \mathrm{KN} / \mathrm{m}^{2}$.

\section{Review: Rice Husk}

Addition of RHA in the expansive soils improves the engineering properties like CBR value and shear strength parameters. UCS value increases value by $48 \%$ at 28 days of curing and CBR value increases by $13 \%$ to $50 \%$ at 14 days of curing. MDD gradually decreases and OMC increases by adding RHA.

Bhasin et al. (1988) made a laboratory study on the stabilization of black cotton soil as a pavement material using RHA, along with other industrial wastes like fly ash, bagasse ash, lime sludge, black sulphite liquor independently with and without lime. The RHA causes greater improvement than that caused by other wastes due to presence of higher percentage of reactive silica in it. In combination with lime, RHA improved the properties of black cotton soil significantly.

Muntohar and Hantoro (2000) [10] had studied the stabilizing effects of RHA and lime on engineering properties of expansive soil and had found improvement in engineering properties like IP, CBR, shear strength parameters, Sp etc.

Basha et al. (2003) had studied the effects of RHA and cement on plasticity 
and compaction properties of expansive soil (bentonite) and had recommended that $10 \%-15 \%$ of RHA and $6 \%-8 \%$ of cement as optimum percentages for stabilization.

Ramakrishna and Pradeep Kumar (2006) [11] had studied combined effects of RHA and cement on engineering properties of black cotton soil. From strength characteristics point of view they had recommended $8 \%$ cement and 10\% RHA as optimum dose for stabilization.

Sharma et al. (2008) had investigated the behavior of expansive clay stabilized with lime, calcium chloride and RHA. The optimum percentage of lime and calcium chloride was found to be $4 \%$ and $1 \%$ respectively in stabilization of expansive soil without addition of RHA. From UCS and CBR point of view when the soil was mixed with lime or calcium chloride, RHA content of $12 \%$ was found to be the optimum. In expansive soil-RHA mixes, $4 \%$ lime and $1 \%$ calcium chloride were also found to be optimum.

Rao et al. (2011) had studied the effects of RHA, lime and gypsum on engineering properties of expansive soil and found that UCS increased by $48 \%$ at 28 days of curing and CBR increased by $1350 \%$ at 14 days curing at RHA $-20 \%$, lime $-5 \%$ and gypsum $-3 \%$.

Sabat (2012) [1] had studied the effects of polypropylene fiber on engineering properties of RHA-lime stabilized expansive soil. Polypropylene fiber added were $0.5 \%$ to $2 \%$ at an increment of $0.5 \%$. The properties determined were compaction, UCS, soaked CBR, hydraulic conductivity and Ps. The effect of 0,7 and 28 days of curing ware also studied on UCS, soaked CBR, hydraulic conductivity and Ps. The optimum proportion of soil:RHA:lime:fiber was found to be 84.5:10:4:1.5.

Sabat (2013) [2] had studied the effect of lime sludge (from paper manufacturing industry) on compaction, CBR, shear strength parameters, coefficient of compression, Ps and durability of an expansive soil stabilized with optimum percentage of RHA after 7 days of curing. The optimum proportion soil: RHA: lime sludge was found to be $75: 10: 15$.

Ashango and Patra (2014) had studied the static and cyclic properties of clay subgrade stabilized with RHA and Portland slag cement. The optimum percentage of RHA was found to be $10 \%$ and Portland slag cement as $7.5 \%$ for stabilization of expansive soil. They concluded that the stabilized expansive soil was found suitable for subgrade of flexible pavement as, there was significant increase in strength and the stabilized soil was durable.

Aparna Roy (2014), had studied the effect of rice husk ash on black cotton soil and she concluded that, the soft soil is identified to be clay of high plasticity $(\mathrm{CH})$ according to IS Soil Classification System. It has very low CBR-value (1.46) and unconfined compressive stress $\left(70 \mathrm{KN} / \mathrm{m}^{2}\right)$. The soil is required to be stabilized before doing any construction work. Treatment with RHA and a small percentage of cement shows a general decrease in the MDD and increase in OMC with increase in the RHA content. There is also an improvement in the unsoaked CBR (106\% at 10\% RHA content) compared with the CBR of the natural soil. A similar trend is obtained for UCS. The UCS value is at its peak at 10\% RHA $(90.6 \%$ 
improved). For maximum improvement in strength, soil stabilization using 10\% RHA content with $6 \%$ cement is recommended as optimum amount for practical purposes.

\section{Conclusions}

From the above review of literature on stabilization of expansive soil using industrial solid waste the following conclusions were drawn.

Stabilization of expansive soil using industrial solid waste improves the geotechnical properties (like index properties, compaction properties, UCS, CBR, and swelling properties) of expansive soil.

By adding $15 \%$ of granite waste and quarry dust in the soil, it gives modified geotechnical properties.

From the review of literature on stabilization of expansive soil using solid wastes, the following conclusions are drawn:

- Stabilization of expansive soil using solid wastes improves the geotechnical properties of expansive soil.

- Majority of the researchers have discussed the effects of stabilization on index properties, compaction properties, UCS, CBR and swelling properties of expansive soil.

- The effects of stabilization on, consolidation properties, shear strength, splitting tensile strength, stiffness and hydraulic conductivity of expansive soil have not been studied by most of the researchers.

- Investigations on, effects of contaminants on geotechnical properties of stabilized soil, mineralogical studies, durability and economic aspect of stabilization are limited in literature.

- Behaviour of the stabilized soil subjected to cyclic loading is also limited in literature.

- It is possible to use of the CKD as partial replacement of PC, in combination with pozzolanic materials, like fly ash, blast furnace slag, etc.

- The studies regarding the use of the solid wastes as stabilizer have been mostly confined to strengthen the sub-grade of pavement. However the studies regarding the use of the solid wastes stabilized expansive soil in other areas like, liner material in engineered landfill, backfill material in retaining wall, base and sub-base material in pavement and cushion material in pavement, are negligible in literature.

- The Marble Powder is added about $15 \%$ to the soil as strength point of view, results in the modification of the expansive soil in to low plasticity and silty behaviour.

- Future research on the stabilization of expansive soil using solid wastes should be undertaken by taking into consideration, the above issues.

From the above literatures we can conclude that the stabilization of expansive soil increases with increase in the percentage of admixtures added for stabilizing. 


\section{References}

[1] Sabat, A.K. (2012) A Review of Literature on Stabilization of Expansive Soil Using Solid Waste. EJGE, 19, 6251-6267.

[2] Sabat, A.K. and Bose, B. (2013) Expansive Soil Stabilization Using in Dustrial Solid Wastes. IJATES, 4, 636-646.

[3] Singh, P.S. (2014) Effect of Marble Dust on Index Properties of Black Cotton Soil. IJERST, 3, 158-163.

[4] Patidar, A. and Mahiya, H.K. (2014) Experimental Study on Stabilization of Black Cotton Soil Using Hdpe Wastage Fibres, Stone Dust \& Lime. International Journal of Advanced Scientific and Technical Research, 6.

[5] Mishra J., Yadav, R.K. and Singhai, A.K. (2014) Effect of Granite Dust on Engineering Properties of Lime Stabilized Black Cotton Soil. IJERT, 3, 832-837.

[6] Muthu Kumar, M. and Tamilarasan, V.S. (2015) Experimental Study on Expansive Soil with Marble Powder. IJETT, 52, 12-16.

[7] Venkateswarlu, H., et al. (2015) Study on Behavior of Expansive Soil Treated With Quarry Dust. IJEIT, 4, 193-196.

[8] Mishra, B. and Mishra, R.S. (2015) Improvement in Characteristics of Expansive Soil by Using Quarry Waste and Its Comparison with Other Materials like Cement and Lime Being Used for Soil Improvement. International Journal of Innovative Research in Science, Engineering and Technology, 4, 7416-7431.

[9] Oriola, F.O.P. and Moses, G. (2011) Compacted Black Cotton Soil Treated with Cement Kiln Dust as Hydraulic Barrier Material. American Journal of Scientific and Industrial Research, 2, 521-530. https://doi.org/10.5251/ajsir.2011.2.4.521.530

[10] Muntohar, A.S. and Hantoro, G. (2000) Influence of Rice Husk Ash and Lime on Engineering Properties of a Clayey Subgrade. Electronic Journal of Geotechnical Engineering, 5, 1-13.

[11] Ramakrishna, A.N. and Pradeep Kumar, A.V. (2006) Stabilisation of Black Cotton Soil Using Rice Husk Ash and Cement. National Conference on Civil Engineering Meeting the Challenges of Tomorrow, GND Engineering College, Ludhiana, 215-220. 